УДК 159.9.07

https://doi.org/10.52058/2708-7530-2021-10(16)-402-411

Корсакевич Святослав Сергійович здобувач ступеня Phd, Інститут соціальної і політичної психології, Національної академії педагогічних наук України, вул. Андріївська, 15, м. Київ, 04070, e-mail: sviatoslavsergeevych@gmail.com, https://orcid.org/0000-0001-9315-2035

\title{
УЯВЛЕННЯ МОЛОДІ ПРО СЕБЕ, ЯК ПРО ВИБОРЦЯ У КОНТЕКСТІ ПОЛІТИЧНОГО САМОВИЗНАЧЕННЯ: ЕМПІРИЧНА МОДЕЛЬ I ЇЇ КОНФІГУРАЦІЯ
}

Анотація. Актуальність представлених у статті матеріалів емпіричного дослідження відповідає сучасним запитам суспільства щодо знання про політичне самовизначення виборців, серед яких значну кількісну частину складає молодь.

Складність і багатоаспектність процесу політичного самовизначення призводить до припущення про існування різних типів або напрямків формування й реалізації цього явища. I для того, щоб підтвердити або спростувати такі гіпотетичні роздуми було проведено дослідження з урахуванням теоретичних наукових доробків $з$ даної теми.

Таким чином перехід від теоретичної моделі до емпіричної, з отриманими конкретними значеннями у процесі дослідження, може слугувати описом реальних молодіжних тенденцій у процесі самовизначення молоддю себе, як виборця та громадянина.

Мета статті полягає у висвітлені багатоаспектності феномену самовизначення молоді щодо участі у виборчому процесі 3 подальшим впорядкуванням даного психолого-політичного явища за типами (факторами) та описом отриманих емпіричних результатів.

Метод і методологічні засади дослідження. Дослідження проводилось у два етапи, і в обох випадках було організовано на платформі Google-Forms. 3 одного боку це зручний метод збирання та конвертації даних, а з іншого обумовлено ситуацією дистанційного навчання/роботи молоді. Перший етап: збір даних тривав 3 вересня по жовтень 2020 року. Вибірку склали 44 представника молоді віком від 18 до 35 років, з яких 27 чоловіків та 17 жінок. Склад вибірки на 3/4 склали містяни і на $1 \frac{1}{4}$ жителі сільської місцевості.

В рамках першого етапу, який став пілотажним, 3 поміж іншого, було запропоновано онлайн-анкету 3 відкритими питаннями стосовно виборчого процесу, його значення та свого місця в ньому для кожного із учасників опитування. Для аналізу даних, з поміж інших, використовувався контент-аналіз.

Другий етап: збір даних тривав з грудня 2020 року по березень 2021 року. Вибірку склали 329 молодих людей, віком від 18 до 35 років, відповідно 
147 - чоловіків та 182 - жінки, у більшості своїй містяни.

В рамках другого етапу, який став основним емпіричним дослідженням 3 теми саме психологічних особливостей самовизначення молоді щодо участі у виборчому процесі, було сформовано батарею методик, які увійшли до загальної анкети. Одна з частин анкети відображала міру визначення себе, як виборця, виходячи із семантичного диференціалу з опозиційними смисловими полюсами, які були задані на основі матеріалів попереднього етапу і їх контент-аналізу.

Результати дослідження показали, що поряд із такими конструктами самовизначення під час виборчого процесу як «зацікавлений», «аналізуючий», «відповідальний» та ін. зустрічаються чимало виборів наближені до протилежного полюсу, таких як «байдужий», «діючий спонтанно», «ненадійний» та ін.

Оцінено характер репродуктивних установок вибірки щодо виборчого самовизначення. Отримана також значуща вираженість структурних складових, яка свідчить про те, що лише один з чотирьох факторів лежить у позитивній (ефективній) площині координат семантичного диференціалу стосовно виборчого самовизначення молоді.

Висновки. Узагальнення результатів дослідження дає підстави стверджувати що $\epsilon$ певна конфігурація факторів, які спрямовують процес політичного самовизначення молоді в умовах виборів. Кожен 3 факторів поєднує в собі ті складові, які є визначальними при усвідомленні себе, як виборця, і можемо припустити що саме ці складові проявляються на рівні психологічних особливостей у поведінці та діях молоді під час участі у виборчих процесах.

3 поміж чотирьох факторів самовизначення молоді щодо участі у виборчому процесі, лише один несе позитивне семантичне забарвлення, i як наслідок ефективність у реалізації своїх громадянських та виборчих прав.

Практична значущість дослідження полягає в можливості використання отриманих результатів для розроблення рекомендацій і програм по роботі 3 молоддю, які сприятимуть більш ефективному самовизначенню у складних та неоднозначних процесах політичної дійсності.

Ключові слова: самовизначення; політичне самовизначення; самовизначення щодо участі у виборчому процесі; молодь; фактори молодіжного виборчого самовизначення; структурні складові.

Korsakevych Sviatoslav Serhiyovych Candidate of Phd in the field of «Political Psychology», Institute of Social and Political Psychology of the National Academy of Pedagogical Sciences of Ukraine, Andriyivska St., 15, Kyiv, 04070, e-mail: sviatoslavsergeevych@gmail.com, https://orcid.org/0000-0001-9315-2035

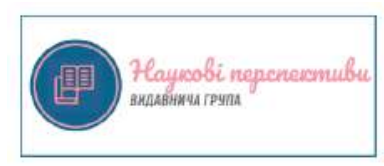




\title{
YOUNG PEOPLE'S PERCEPTION OF HIMSELF AS A VOTER IN THE CONTEXT OF POLITICAL SELF-DETERMINATION: EMPIRICAL MODEL AND CONFIGURATION
}

\begin{abstract}
The relevance of the materials presented in the article of the empirical study meets the modern demands of society for knowledge about the political selfdetermination of voters, among whom a significant part is young people.

The complexity and multifaceted nature of the process of political selfdetermination leads to the assumption of the existence of different types or directions of formation and implementation of this phenomenon. And in order to confirm or refute such hypothetical considerations, a study was conducted taking into account the theoretical scientific achievements on this topic.

Thus, the transition from a theoretical model to an empirical one, with specific values obtained in the research process, can serve as a description of real youth trends in the process of self-determination by young people of themselves as voters and citizens.
\end{abstract}

The purpose of the article is to highlight the multifaceted phenomenon of youth self-determination in terms of participation in the electoral process with the subsequent organization of this psychological and political phenomenon by types (factors) and a description of the obtained empirical results.

Method and methodological principles of research

The research was conducted in two stages, and in both cases was organized on the Google-Forms platform. On the one hand, it is a convenient method of data collection and conversion, and on the other hand, it is due to the situation of distance learning / youth work. The first stage: data collection lasted from September to October 2020. The sample consisted of 44 young people aged 18 to 35, including 27 men and 17 women. The sample consisted of citizens and rural residents.

As part of the first pilot phase, among other things, an online questionnaire was offered with open-ended questions about the election process, its significance and its place in it for each of the respondents. For data analysis, among others, content analysis was used.

The second stage: data collection lasted from December 2020 to March 2021. The sample consisted of 329 young people, aged 18 to 35, respectively - 147 men and 182 women, most of them citizens.

Within the framework of the second stage, which became the main empirical research on the topic of psychological features of youth self-determination regarding participation in the electoral process, a battery of methods was formed, which were included in the general questionnaire. One part of the questionnaire reflected the measure of defining oneself as a voter, based on the semantic differential with oppositional semantic poles, which were set on the basis of the materials of the previous stage and their content analysis.

The results of empirical research showed that along with such constructs of self- 
determination during the election process as "interested", "analyzing", "responsible" and others. There are many elections close to the opposite pole, such as "indifferent", "acting spontaneously", "unreliable" and others.

The nature of the sample 's reproductive attitudes towards electoral self determination was assessed. Significant expression of structural components was also obtained, which indicates that only one of the four factors lies in the positive plane of the coordinates of the semantic differential in relation to the electoral selfdetermination of young people.

There was a statistically significant relationship $(\mathrm{p}<0.01)$ between individual perceptions of young people's self-determination to participate in the electoral process, for example: "tolerant", "realistic", and on the other hand "conservative".

Conclusions. The generalization of the research results gives grounds to assert that there is a certain configuration of factors that guide the process of political selfdetermination of young people in the election environment. Each of the factors combines those components that are decisive in understanding oneself as a voter, and we can assume that these components are manifested at the level of psychological characteristics in the behavior and actions of young people during participation in electoral processes.

Of the four factors of young people's self-determination to participate in the electoral process, only one has a positive semantic color, and as a consequence, efficiency in the exercise of their civil and suffrage rights.

The practical significance of the research consist in the possibility of using the results to develop recommendations and programs for working with young people that will contribute to more effective self-determination in the complex and ambiguous processes of political reality.

Keywords: self-determination; political self-determination; self-determination regarding participation in the election process; young; factors of youth electoral selfdetermination; structural components.

Постановка проблеми. Наукові дослідження феномену самовизначення молоді щодо участі у виборчому процесі зустрічаються у політичних, філософських та інших науках. При цьому, меншою мірою пояснюється цей феномен через психологічні особливості, які на нашу думку мало дослідженні у контексті політичного самовизначення, а саме у контексті виборчої участі молоді під час виборчих кампаній.

Політичне самовизначення представлено як специфічний політикопсихологічний феномен, що проявляється в думках, словах та діях особистості.

Така ситуація вимагає від молоді політичної компетентності i психологічної зрілості, а значить, визначеності в питаннях щодо політичного життя України.

Таким чином вивчення феномену політичного самовизначення кожного громадянина, психології електорату під час виборчих процесів $є$ актуальним

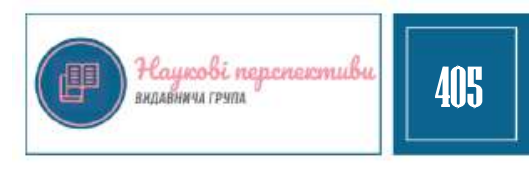


науковим завданням [8].

Аналіз останніх досліджень і публікацій. На попередньому етапі було використано результати таких наукових досліджень (А. Краснякова, 2014; Л. Кияшко, 2014; В. Мельниченко 2001, 2013; М. Сидоркіна 2013, 2014, 2017 ; В.Торяник 2006, 2013; І. Хорт, 2010; та ін. Серед зарубіжних дослідників слід виділити Х.Берана 1998, Ч. Веллмана, 1995; К. Каллахона, 1992; К. Каннігхема, 2014; А. Шедлера, 2012.)

Також були взяті до уваги наукові розвідки та результати Малиш, 2019; Позняк, 2019; Резнік, 2019; Скнар,2019; та ін.

Аналіз наукових доробок вищеописаних дослідників дає нам підстави для припущення, що самовизначення, в тому числі й у політичних процесах, має психологічну природу разом із своїми особливостями для кожного окремого випадку [11]. Це в свою чергу вимагає підтвердження або спростування шляхом застосування відповідного теоретичного та емпіричного інструментарію.

Враховуючи непрості суспільно-політичні події в державі, до яких можуть належати i віськові дії на Сході України, i зростання міграційних процесів населення, і масові заходи щодо попередження вірусної епідемії, і звісно стихійні і по-новому обумовлені виборчі процеси (вибори Президента України 2019 р., вибори до Верховної Ради України 2019 р. та місцеві вибори 2020 р.) доречно зауважити - все це додає труднощів в процеси самовизначення, тим паче політичного самовизначення, ускладнюючи усвідомлення важливості власного політичного вибору для громадянина. Адже такий вибір впливатиме в майбутньому як на психологію самого суб єкта вибору щодо державної політики і власної участі в цьому процесі, так і на впровадження декларованої політики обраного об єкту політичного вибору 3 подальшим уявленням об єкту політичного вибору про свого виборця [4].

Керуючись такою логікою стає зрозуміло, чому автор даної статті провів емпіричне дослідження у 2020-2021 році, яке дає можливість поглянути на самовизначення молоді щодо участі у виборчому процесі з психологічної, такої актуальної сторони даного феномену на сьогоднішній день.

Мета статті - визначити конфігурацію основних факторів, які зумовлюють самовизначення молоді щодо участі у виборчому процесі.

За результатами дослідження передбачається:

1) визначити структуру та конфігурацію факторів, які $\epsilon$ провідними у процесах політичного самовизначення в умовах виборчого процесу

2) оцінити ступінь вираження факторів і їх особливостей

3) виявити найбільш раціональні фактори, як своєрідні вектори усвідомленого і відповідального самовизначення молоді щодо участі у виборчому процесі.

Виклад основного матеріалу. Проаналізувавши теоретичні моделі та наукові джерела 3 теми політичного самовизначення молоді. Ознайомившись 3 результатами соціологічних досліджень, дотичними до теми виборчого 
самовизначення, 3 свіжих можна згадати опитування на місцевих виборах в Україні 2020 року проведеного соціологічною групою «Рейтинг». Де найменш активною на місцевих виборах виявилась молодь. Усього 11\% 3 тих, хто прийшли на вибори, були люди віком 18 - 29 років. У загальній структурі виборців їх - 18\%. А отже більша частина молодих людей відповідно до вікового діапазону, який визначає Закон України «Про сприяння соціальному становленню та розвитку молоді в Україні», просто не прийшли на вибори. Серед причин неявки виборців на дільниці, соціологи групи «Рейтинг» виділяють 3 поміж інших такі: старші люди не йшли на вибори через стан здоров’я, а молодь у день виборів була зайнятою. Отже враховуючи усе вищеописане, наше дослідження, яке і спрямоване на визначення психологічної складової феномену виборчого самовизначення молоді, стає дедалі вагомішим. Адже у нашому дослідженні розглядаються ті аспекти, які можуть пояснити таку виборчу активність та поведінку молоді.

Важливим етапом роботи є добирання адекватного інструментарію для проведення емпіричного дослідження [2]. Виходячи 3 мети і завдань нашого емпіричного дослідження та спираючись на теоретичну структуру самовизначення молоді щодо участі у виборчому процесі було сконструйовано відповідний комплекс методик для емпіричного дослідження цікавого нам політико-психологічного феномену.

Вибірка. У дослідженні взяли участь 329 осіб молодого віку. Вік досліджуваних становив від 18 до 35 років. Серед них за статтю 147 - чоловіків та 182 - жінки. За критерієм віку вибірку було поділено на 4 вікові групи: 1) 18-22 роки (135 учасників); 2) 22-26 роки (83 учасника); 3) 26-32 роки (36 учасників); 4) 32-35 років (75 учасників). Як бачимо, найбільш активними у заповненні онлайн-анкети i проходженні дослідження виявилися наймолодші учасники. Такий поділ за віком відповідав життєвим умовам та сферам діяльності молоді ( студенство-навчання, працевлаштування i перший професійний досвід, подальше професійне та особистісне становлення). Усі досліджувані - жителі міст та сел України. Більшість - містяни.

\section{Виклад методики, опису та результатів дослідження.} У дослідженні використовувався такий комплекс методик та методів дослідження: опитувальник рефлексивності А.В.Карпова - В.В. Пономарьової, анкета для визначення емоційної спрямованості самооцінки Білобрикіної, короткий опитувальник рівня політичної участі Кияшко\&Краснякова, анкета фактору соціальної сміливості за методикою 16Р опитувальника Кеттела, тестопитувальник мотивації схвалення С.Марлоу-Крауна. 3 поміж інших було використано метод семантичного диференціалу Ч. Осгуда.

Для обробки результатів використано методи математичної статистики: факторний аналіз (для мінімізації кількості змінних і концентрації інформації про основні типи самовизначення молоді щодо участі у виборчому процесі у формі невеликого масиву даних) за методом головних компонент (РСА) $\mathrm{i}$

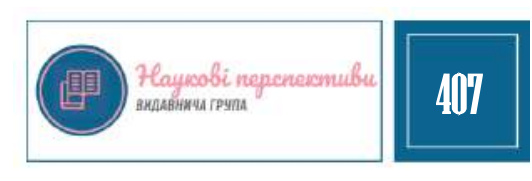


обертанням Varimax 3 нормалізацією Kaizer.

Обробку отриманих емпіричних результатів здійснено за допомогою комп'ютених програм для статистичної обробки даних (програми R-project, SPSS Statistics 23.0.).

Дослідження самовизначення молоді щодо участі у виборчому процесі проводилося у два етапи: перший етап включав проведення пілотажного дослідження 3 використанням методу контрольованого асоціативного експерименту в рамках якого, було отримано перелік слів-реакцій (якостейособливостей) на слова-стимули «виборець», «участь у виборах». Отримані асоціації за критерієм семантичної близькості-віддаленності було погруповано у 15 категорій слів протилежних за значенням, які були відображені в основному дослідженні у формі семантичного диференціалу. В ході другого етапу використовувався метод суб’єктивного шкалювання. Досліджувані оцінювали ступінь вираженості у себе виокремлених якостей . А саме, було запропоновано обрати міру згоди на шкалі протилежних значень від 1 до 7 представленими словами і їх змістом. Досліджуваним пропонувалося дати відповідь на запитання « Як Ви визначаєте себе, як виборець? » 3 варіантами відповіді, наприклад: «Неправдивий» це -1 , а «Чесний» відповідно - 7.

У результаті факторного аналізу уявлень молоді про їх самовизначення щодо участі у виборчому процесі зі значенням від 1 до 7 на семантичному диференціалі, методом головних виділилося 4 фактори (F), що пояснюють близько 60 \% дисперсії (рис. 1)

\begin{tabular}{|l|l|l|l|}
\hline $\mathbf{1 F}$ & $\mathbf{2 F}$ & $\mathbf{3 F}$ & $\mathbf{4 F}$ \\
\hline Реактивно-інерційний & Апатичний (аморфний) & Емоційний & $\begin{array}{l}\text { Раціональний } \\
\text { (ефективний) }\end{array}$ \\
\hline $\begin{array}{l}\text { Неправдивий } \\
(0,783)\end{array}$ & $\begin{array}{l}\text { Пасивний } \\
\text { Упереджений }\end{array}$ & $\begin{array}{l}\text { Емоційний } \\
(0,803)\end{array}$ & $\begin{array}{l}\text { Толерантній } \\
(0,722)\end{array}$ \\
$(0,743)$ & $\begin{array}{l}\text { Байдужий } \\
\text { Діючий спонтанно }\end{array}$ & $\begin{array}{c}\text { Консервативний } \\
(0,691)\end{array}$ \\
$\begin{array}{l}\text { Збентежений } \\
(0,670)\end{array}$ & $(0,595)$ & Реалістичний \\
Ненадійний & Необізнаний & & $(0,600)$ \\
$(0,615)$ & $(0,552)$ & & \\
Залежний & Уникаючий негативного \\
$(0,446)$ & $(0,514)$ & & \\
\hline
\end{tabular}

\section{Puc. 1}

Перший фактор - «Реактивно-інерційний» - є багатополюсним. Об’єднує такі конструкти: «неправдивий», «упереджений», «збентежений», «ненадійний», які відображають уявлення молоді віком від 18 - 35 років про самовизначення себе, як виборця, в процесі участі у виборчому процесі . Другий фактор «Апатичний(аморфний)» - включає конструкти «пасивний», «байдужий», 
«необізнаний», «уникаючий негативного», «невпевнений» які є свідченням того, що потенційні виборці серед молоді в Україні схильні до пасивної політичної поведінки, свою виборчу активність вони не розцінюють як шлях до позитивних змін, радше як шлях мінімізації негативних впливів політичного сьогодення i можемо припустити, що це є наслідком в тому числі необізнаності про свої права та можливості, як виборця. Третій фактор - «Емоційний» - включає конструкти «емоційний», «діючий спонтанно», на відміну від своїх протилежних значень «раціональний» та «аналізуючий», отримані дані висвітлюють що досліджувані уявляють себе під час виборів у деякому збудженому стані, готовими до дій скоріше ситуативно, спонтанно, ніж виважено та усвідомлено, адже такі насичені емоціями та переживаннями, припускаємо, стани, дещо звужують можливість особистості об'єктивно оцінити виборчий процес і побачити у більш об'єктивних тонах виборчу картину. Четвертий фактор - «Раціональний (ефективний) » - його конструкти наступні: «толерантний», «консервативний», «реалістичний».

Виявлено також значущі зв’язки кожного описаного фактору із результатами опитувальника, що вимірював рівень політичної участі кожного із респондентів(Короткий опитувальник рівня політичної участі Кияшко\&Краснякова) [7]. Можемо припустити, що це свідчить про пряму позитивну кореляцію між факторами самовизначення молоді у виборчому процесі і мірою залучення до політичної участі у країні. Наприклад фактори: «Реактивно-інерційний», «Апатичний (аморфний)», «Емоційний» корелюють із низьким та середнім рівнем політичної участі. А от 4-й фактор «Раціональний (ефективний)» корелює із високим рівнем політичної участі. Це також свідчить 3 одного боку, що лише чверть учасників дослідження визначають себе у ролі виборців як: терплячі до розмаїття політичних сил i процесів громадяни із власними чіткими правилами щодо участі у виборчому процесі. А 3 іншого, що саме такий так би мовити тип виборця забезпечує усвідомлену і в міру активну участь у політичних процесах в державі.

Висновки. Електоральне самовизначення молоді, або самовизначення щодо участі у виборчому процесі - це довготривалий і динамічний процес із багатьма змінними, який визначає роль та місце молодої людини у політичній реальності.

До вагомих особливостей такого самовизначення слід віднести психологічні, в тому числі й уявлення молоді про себе, як про громадянина здатного виконувати основну функцію і право електорату - обирати та віддавати свій голос на користь кандидата, політичної сили під час виборчого процесу.

Результати дослідження підказують, що певно існує якась структура зі своїм нетривіальним змістом, так би мовити типів виборця, який керується неоднаковими векторами у визначенні, співставленні себе, уявленнями про себе в умовах виборної кампанії. На прикладі нашого дослідження можемо попередньо припустити, що молодь, більшою мірою, самовизначається малоефективно, будучи носієм громадянських прав та обов'язків, які дозволяють прямим інструментом впливати на розстановку сил на політичному терені, у своїй 
більшості молодь ставиться до цього скептично, проявляючи недовіру, байдужість.

Лише чверть молодих людей, які брали участь в опитуванні, асоціюють себе як толерантні, реалістичні і при цьому консервативні виборці.

У статті описані отримані у ході дослідження чотири фактори, уявлення або так би мовити типи виборця і складові його самовизначення у виборчому процесі. Змістові складові цих типів мають різну міру вираженості. I тільки одному з них, який ми назвали «Реалістичний (ефективний) » притаманні значущі зв'язки із високим рівнем політичної участі, в той час як інші три типи мають зв'язок у рамках статистичної значущості із низьким та середнім рівнем політичної участі.

Такий стан справ дає підстави припустити, що притаманна українській політиці непланомірність, деяка невизначеність, невпорядкована зміна політичних сил та ідеологій або їх відсутність створили досить унікальну систему політичної культури. В останній, вочевидь є чимало прогалин та тригерів для молоді, які викликають у свідомості молоді неоднозначне уявлення про себе, як про виборця.

Перспективи практичного застосування результатів полягають у використанні напрацьованого матеріалу при розробці партисипаційних, політично-просвітницьких заходів для молоді та при врахуванні сучасних навчальних програм для студентів, а також проектів, в яких торкаються тем політичного самовизначення, політичної участі сучасного громадянина.

\section{Лimepamypa:}

1. Васютинський В. О. (1997) Психологія масової політичної свідомості та поведінки. Київ : Док-К.163.

2. Дворник, M. (2020). Електронна підтримка психологічного благополуччя військовослужбовців: первинний аналіз даних. Проблеми політичної психологї̈, 23(1), 54-71. https://doi.org/10.33120/popp-Vol23-Year2020-46

3. Дроздов, О. (2018). Геополітичнний образ майбутнього молоді з різних регіонів України в контексті психологічної безпеки. Проблеми політичної психологї, 21(1), 113-127. https://doi.org/10.33120/popp-Vol21-Year2018-9

4. Жадан, I. (2011) Політична соціалізація. Політична енциклопедія. Київ: Парламентське видавництво. 590.

5. Инглхарт Р. (1997). Постмодерн: меняющиеся ценности и изменяющиеся общества. Журнал Полис. Политические ислледования. №4. 6 - 32.

6. Karkovska R. Psychological factors of the image of the state in the students' perception / R. Karkowska // Journal of Education Culture and Society. - 2014. - No.1. - P. 158-168.

7. Кияшко, Л.О, Полунін, О.В, Краснякова, А.О, Сидоркіна, М.Ю. (2014) Політична участь молоді сучасної України: психологічні чинники активізації. Київ: Міленіум. 215.

8. Корсакевич, С. (2020). Політичне самовизначення молоді: соціально-психологічні особливості. Проблеми політичної психологї, 23(1), 183-194. https://doi.org/10.33120/poppVol23-Year2020-52

9. Koestner, R., Losier, G. F., Vallerand, R. J., \& Carducci, D. (1996). Identified and introjected forms of political internalization: Extending self-determination theory. Journal of Personality and Social Psychology, 70, 1025-1036.

10.Найдьонов М. I. Геополітичний вибір: передумови та наслідки дисбалансу очікувань громадської думки і державної політики / М. І. Найдьонов, Л. В. Григоровська, Л. А. Найдьонова // 
Проблеми політичної психології: Зб. наук. праць. - К., 2014. - Вип. 1 (15). - С. 223-237.

11. Наследов, А. А. Математические методы психологических исследований. Анализ и интерпретация данных / А. А. Наследов. - СПб. : ООО “Речь”, 2004. - 392 с.

12. Скнар, О. (2018). Дискурс громадянської та національної ідентичності: Конструкти самосвідомості молоді. Проблеми політичної психологї̈, 21(1), 139-149. https://doi.org/10.33120/ popp-Vol21-Year2018-11

\section{References:}

1. Vasjutins'kij, V. O. (1997) Psihologija masovoï politichnoï svidomosti ta povedinki [Psychology of mass political consciousness and behavior]. Kiïv : Dok-K [in Ukrainian].

2. Dvornik, M. (2020). Elektronna pidtrimka psihologichnogo blagopoluchchja vijs'kovosluzhbovciv: pervinnij analiz danih [Electronic support of psychological well-being of servicemen: primary data analysis]. Problemi politichnoï psihologii - Problems of Political Psychology, 23(1), 54-71 [in Ukrainian].

3. Drozdov, O. (2018). Geopolitichnnij obraz majbutn'ogo molodi z riznih regioniv Ukraïni v konteksti psihologichnoï bezpeki [Geopolitical image of the future of young people from different regions of Ukraine in the context of psychological security]. Problemi politichnoï psihologii Problems of Political Psychology, 21(1), 113-127 [in Ukrainian].

4. Zhadan, I. (2011) Politichna socializacija. Politichna enciklopedija [Political socialization. Political encyclopedia]. Kiïv: Parlaments'ke vidavnictvo [in Ukrainian].

5. Inglhart, R. (1997). Postmodern: menjajushhiesja cennosti i izmenjajushhiesja obshhestva [Postmodernism: changing values and changing societies]. Zhurnal Polis. Politicheskie islledovanija Polis Magazine. Political research, 4. 6-32 [in Ukrainian].

6. Karkovska, R. (2014). Psychological factors of the image of the state in the students' perception [Psychological factors of the image of the state in the students 'perception]. Journal of Education Culture and Society, 1, 158-168 [in English].

7. Kijashko, L.O, Polunin, O.V, Krasnjakova, A.O, Sidorkina, M.Ju. (2014) Politichna uchast' molodi suchasnoï Ukraïni: psihologichni chinniki aktivizaciï [Political participation of young people in modern Ukraine: psychological factors of activation]. Kiïv: Milenium [in Ukrainian].

8. Korsakevich, S. (2020). Politichne samoviznachennja molodi: social'no-psihologichni osoblivosti [Political self-determination of youth: socio-psychological features]. Problemi politichnoï psihologii - Problems of Political Psychology, 23(1), 183-194 [in Ukrainian].

9. Koestner, R., Losier, G. F., Vallerand, R. J., \& Carducci, D. (1996). Identified and introjected forms of political internalization: Extending self-determination theory [Identified and introjected forms of political internalization: Extending self-determination theory.]. Journal of Personality and Social Psychology, 70, 1025-1036. [in English].

10. Najd'onov, M. I. (2014). Geopolitichnij vibir: peredumovi ta naslidki disbalansu ochikuvan' gromads'koï dumki i derzhavnoï politiki [Geopolitical choice: preconditions and consequences of the imbalance of expectations of public opinion and public policy]. Problemi politichnoï psihologii Problems of political psychology 1 (15), 223-237 [in Ukrainian].

11. Nasledov, A. A. (2004). Matematicheskie metody psihologicheskih issledovanij. Analiz $i$ interpretacija dannyh [Mathematical methods of psychological research. Analysis and interpretation of data]. SPb. : OOO "Rech"” [in Ukrainian].

12. Sknar, O. (2018). Diskurs gromadjans'koï ta nacional'noï identichnosti: Konstrukti samosvidomosti molodi [Discourse of civic and national identity: Constructs of youth self-awareness]. Problemi politichnoï psihologi - Problems of Political Psychology 21(1), 139-149 [in Ukrainian].

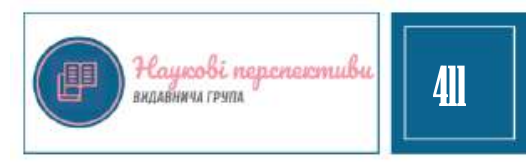

